\title{
Virtues, Consequences, and the Market
}

\author{
BENJAMIN FERGUSON \\ University of Warwick \\ Vrije University Amsterdam
}

\section{INTRODUCTION}

A traditional-but increasingly unconvincing-critique of markets challenges their superiority in terms of generating welfare. After all, markets can be alienating, they can generate inequality, and, arguably, allow for the exchange of goods that ought not to be traded. If these effects collectively made people who live in market societies worse off than those who do not, the implementation of markets would be unacceptable. However, while markets do have some of these negative effects, the welfare and material benefits they provide are massive. In Do Markets Corrupt our Morals? Virgil Storr and Ginny Choi provide substantial evidence for the conclusion that not only are "people who live in market societies [...] wealthier, healthier, happier, and better connected than people who live in nonmarket societies" but these benefits are available to the rich and poor alike: "The least advantaged in market societies are better off than the least advantaged in nonmarket societies and may be better off than the most well-off in some nonmarket societies" (13).

However, responding to this traditional critique is not Storr and Choi's primary aim. Instead, they focus on a more nuanced critique. This critique accepts that markets produce the aforementioned material benefits, but counters that the real problem with markets is that they come at the cost of our ethical integrity. Call this the virtue-based critique (VC). The VC claims that

VC1 "Vice is more prevalent in market societies than in nonmarket societies and virtue is less prevalent in market societies than in nonmarket societies."

AUTHOR's NOTE: I thank Marina Uzunova for helpful comments and suggestions. Funding was provided by Nederlandse Organisatie voor Wetenschappelijk Onderzoek (NL) (Grant No. 275-20-063). 
VC2 "As a society becomes more market-oriented and as the scope of the market in a society expands, more vice and less virtue will exist in that society."

VC3 "The more a person engages in market activity, the less virtuous they are likely to be." (44)

Storr and Choi note that both classical and contemporary defenses of markets respond to the traditional critique, but "none of these defenses $[\ldots]$ respond to the $[\mathrm{VC}][\ldots]$ argument that engaging in market activity can corrupt our morals" (65). Some classical responses, like those offered by Bernard Mandeville and Adam Smith, grant VC3 that markets may allow private vice, but they argue that this private vice leads to public virtue and so they reject VC1 and VC2. Other market defenders, such as Philip Wicksteed and Milton Friedman, argue that markets are morally neutral and "are essentially tools that individuals use to further their ends, regardless of their ends" (62). Finally, some defenders argue that markets are moral spaces to a certain degree, but at the same time they accept that markets can also corrupt. This group, which includes Henry Hazlitt, claims that markets are on balance better than the available alternatives. Storr and Choi think these responses are inadequate and concede too much to the VC. They argue:

the claim that markets are morally corrupting is simply wrong. Markets do not work in theory or in practice the way the moral critics and some of the moral defenders of markets contend. (77)

Furthermore, contra VC3, "the more a person engages in market activity, the more virtuous they are likely to be" and, contra VC1 and VC2, "as a society becomes more market-oriented [...] more virtue and less vice will exist in that society" (77).

\section{THREE CONCERNS}

A widely accepted claim about virtue ethics is that virtues are dispositions. According to contemporary analyses of dispositions, they are best understood in counterfactual terms (Quine 1960). One way to cash out this claim about dispositions is to say that $A$ is disposed to $\phi$ under conditions $C$ if and only if $A$ would $\phi$ in some suitable proportion of possible worlds where these conditions obtain (Manley and Wasserman 2008; Fara 
2005). And since virtues are dispositions, by substitution we can say that $A$ has virtue $V$ just in case $A$ would $\phi$ in some suitable proportion of possible worlds where certain conditions obtain. More succinctly, we can say $A$ has virtue $V$ just in case $A$ 's $\phi$-ing is robust. ${ }^{1}$ This claim is a claim about the structure of virtues.

A second widely accepted claim about virtue ethics is that there are many virtues: justice, honesty, compassion, courage, kindness, prudence, faith, hope, and love are amongst the most commonly cited virtues. Since these are all different virtues, they are associated with different actions. For example, honesty is robust truth-telling and, more controversially, love is the robust provision of care (Pettit 2015; Ferguson 2018). This claim is a claim about the content of virtues.

Third, although there is a broad consensus that virtues are dispositions and that there are many of them, there is no consensus about how (or whether) virtues aggregate. So, there is no common agreement about when it is correct to say someone is, on the whole, a virtuous person (apart from the trivial claim that virtuous people are those who, broadly speaking, have virtuous characters). This claim is a (negative) claim about how the aggregation of specific virtues leads to an all-things-considered virtuous character.

I mention these three facts about virtue ethics because I think that despite their claim to directly engage with virtue-based critiques of markets, Storr and Choi have, by and large, provided an indirect response to the VC that ultimately requires rejecting some standard accounts of virtue. And my reasons for thinking that this is the case are related to each of these three facts about virtues. The first, and most minor, concern I have relates to the last point I made about aggregation.

\section{II.I. Aggregation}

Claims VC1-VC3, and Storr and Choi's counterclaims, are aggregate claims, all-things-considered judgements about the quality of an individual's (VC3) or society's (VC1 and VC2) behaviour. If the weights that Storr and Choi place on certain virtues differ from those of their critics, then they may reach different conclusions. For example, a nonmarket society may perform better with respect to kindness, and a market society may perform better with respect to prudence. If Storr and Choi think prudence

\footnotetext{
${ }^{1}$ There are, of course, different ways to exhibit a virtue-we can be kind, generous, or friendly in a variety of ways. So, strictly speaking, to be virtuous is to perform a certain action type robustly (not a specific token action).
} 
carries more weight in determining whether an individual or a society is all-things-considered virtuous than their critics think, then the two will come to different conclusions about which society is more virtuous. Now, neither Storr and Choi, nor their critics (as far as I know) endorse weights or hierarchies of virtues and so this remains primarily a theoretical concern.

One response to this potential problem is to appeal to dominance reasoning. If a market society outperforms a nonmarket society across all virtues, then, regardless of how various virtues are weighed, the market society must be all-things-considered more virtuous. Storr and Choi could argue that this is precisely what they have shown. After all, they show that market societies fare better than nonmarket societies across a wide range of indicators that proxy for virtues. They provide empirical comparisons of market and nonmarket societies with respect to the following virtues and vices: prudence (156), altruism (164), tolerance (172), trust (177), materialism (168), and corruption (170) and they cite McCloskey's (2006) argument that in order to function, markets require certain levels of courage, justice, temperance, prudence, faith, hope, and love. Of course, McCloskey's arguments don't address the comparative challenge in VC2, but they do allay fears in VC1 that market participation erodes certain virtues.

However, I do not think proponents of the VC will be convinced by this dominance reasoning response. First, they may argue that the virtues markets corrupt are not those listed by Storr and Choi, but rather virtues like empathy or being other-regarding. Relatedly, they may challenge whether the empirical evidence Storr and Choi cite is a good proxy for the virtues in question. This brings me to my second concern.

\section{II.II. The Content of Virtue}

An example of the worry about proxies is the evidence that Storr and Choi provide that individuals in market societies are less likely to be materialistic. Here they show that "people in market societies are less likely to view being rich and successful as being important" (168). Furthermore, they argue that attitudes about wealth and success are not explained by a positive attitude towards competition since more people in nonmarket societies think competition is good. They conclude from these results that "the evidence (weakly) suggests that people in market societies are less likely to be materialistic than people in nonmarket societies" (169). 
One factor that may drive this result is the decreasing marginal utility of wealth and success. If, as Storr and Choi argue, people in nonmarket societies are significantly poorer, less healthy, and less happy than those in market societies, they will likely have good reason to care more about being wealthy and successful. Importantly, on Aristotle's account, to be virtuous is not to lack a particular feeling, it is about "having these feelings at the right times, about the right things, toward the right people, for the right end, and in the right way [...] it is a mean between two vices, one of excess and one of deficiency" (Aristotle 1999, 1106b21-1107a3, 2425 ). With this in mind, it is not clear that the stronger feeling of desire for wealth and success experienced by those in nonmarket societies is a vice.

More fundamentally, it is not clear that attitudes towards wealth and success are even appropriate proxies for materialism. Materialism is defined as "a tendency to consider material possessions and physical comfort as more important than spiritual values" (Stevenson 2010). Wealth and success can be variously interpreted, and variously employed. The most charitable interpretation of what animates proponents of the VC is that people in market societies pursue the wrong kinds of wealth and success, rather than focusing on values of the kind that Mill ([1863] 2001) would have called the 'higher pleasures'. Arguably, the pursuit of goods, such as consumer electronics, or fast fashion is more problematic than the pursuit of safe and comfortable housing, or flavourful and nutritious foods. In other words, the VC is concerned with the content of ends that people in markets pursue. It seems that a more appropriate proxy for the vice that proponents of the $\mathrm{VC}$ have in mind would be a per capita measure of advertising expenditures, where market societies will arguably outperform nonmarket societies and thus would rank as more materialistic.

Markets are, on Storr and Choi's definition, "space[s] where the buying and selling of goods and services takes place" and in which people both "compete with one another to secure the goods and services that they desire" and "cooperate with one another to produce and purchase goods and services" (8). As such, markets do not themselves place any constraints on the goods that people trade in them. This fact gives rise to the concern that markets can become noxious when they include certain things that ought not to be for sale (Satz 2010; Sandel 2012). But the materialism concern is importantly different from the problem of noxious markets, for it does not claim that certain goods should not be for sale. Rather, the core of the concern about materialism is that the market's agnosticism allows (and encourages, via advertising) individuals to 
disproportionately pursue the wrong kinds of goods. At root, the problem is that markets require only a commitment to the relatively thin theory of good known as classical liberalism (Mill [1863] 2001; Steiner 1984, 1994; Nozick 1974), which, as Hillel Steiner puts it, "eschew[s] any conception of objective value or human needs, [is] agnostic as between different tastes and preferences, [...] [and] commits itself only to the primacy of personal rights and liberties and to individual choice" (1984, 225). Yet, on the most charitable reading, the VC proponents' concerns about materialism are motivated by perfectionism, which is a theory of the good that specifies particular objective values (Aristotle 1999; Hurka 1993).

One response to this challenge is to argue that properly specified, liberalism is a more plausible theory of value than perfectionism. After all, it imposes few substantive constraints on the ends that individuals may pursue, and thus allows for a high degree of individual liberty. Furthermore, this agnosticism about value allows for a high degree of ecumenism, which allows liberal market societies to be more cosmopolitan in practice.

However, this response is at odds with Storr and Choi's argument. What they want to show is that those values that proponents of the VC are concerned with are actually better instantiated in market societies, and, consequently, if you are moved by the moral considerations that motivate the $\mathrm{VC}$, then you actually have moral reasons to support markets. The response I have sketched above, however, requires a substantive critique of the perfectionist considerations that motivate materialist objections to market societies.

\section{II.III. The Structure of Virtues}

Finally, my third concern relates to the first fact I mentioned: that structurally speaking, virtues are dispositions; robust patterns of behaviour. As Pettit puts it, "You will not count as treating me with honesty [...] just because you tell me the truth under a suitable trigger here and now. After all, you might be happy to do that just because it suits your current purposes for me to know how you take things to be"; rather, to say you have the virtue of honesty means "your telling me the truth must not be dependent on that sort of contingency. It must be the case that you would tell me the truth, for example, even if it was inconvenient for you to do so: even if it thwarted rather than furthered your personal ends" (Pettit $2015,46)$. Virtue requires more than the performance of an action in the 
actual world, it requires that one would also perform the action if things happened to be different, that is, across a range of counterfactual worlds.

An important question is: what is the range of these worlds? It is not infinite, for as Pettit also points out, "I could hardly regard you as dishonest [...] when you [actually] tell me the truth about someone's whereabouts, on the ground that you would not tell me the truth in a variant on actual circumstances in which I want to kill that person, innocent though the person is" (Pettit 2015, 49). So, virtue must be robust to certain changes in actual circumstance, but not to others. Now, specifying the range of virtue's demands is a complicated issue that requires more space than I have available here. What I do want to argue, however, is that many virtues require that actions are robust across changes in circumstance such as profitability. Yet, since markets incentivise responsiveness to profitability considerations, they are, in many cases, incompatible with virtuous behaviour, given the dispositional structure of virtues.

Consider two Aristotelian virtues that Terence Irwin translates as 'individual virtues of character': generosity, and friendliness (Aristotle 1999). Suppose that in the actual world person $A$ performs a friendly act for $B$ but that $A$ wouldn't act in this way if it became unprofitable for him to do so. Surely, though $A$ acts as if he is B's friend, he is not truly a friend (fair weather friends, as the saying goes, are no friends at all). Friendship requires you to treat your friends in friendly ways "not just as a contingent matter: not just as luck or chance or a spasm of good will would have it" (Pettit 2015, 2). Similarly, actual charitable donations do not signify the virtue of charity if they are contingent on, for example, the availability of tax deductions. These considerations generalise to many of the virtues that Storr and Choi consider: altruism, trust, corruption, and tolerance.

Storr and Choi do include the following caveat: "While we would want to assess the reasons why individuals act or feel the way that they do, we do not have direct access to people's motivations" and they point out that "being virtuous and behaving virtuously are not disconnected" (250). Yet, we do not need direct access to agents' internal states to assess the robustness of their behaviour. Both natural and lab-based experiments can examine how and whether variations in incentive structures can lead agents to modify their behaviour. More importantly though, I think Storr and Choi have a substantive disagreement with standard virtue ethical assumptions about the scope of robustness. In their comments on entrepreneurialism and the discussion of the virtue of prudence, they suggest that sensitivity to the profit motive is morally commendable: 
Prudent entrepreneurs, for instance, will notice and exploit opportunities to earn a profit by buying a good at a lower price and selling that good at a higher price. That the same good is selling at different prices is an error in need of correction; the price discrepancy means that some producer is selling her wares for too low a price and some consumer is buying the goods he wants at too high a price. Prudent entrepreneurs will be alert to the existence of these errors and will exploit these arbitrage opportunities because of their desire for profits. (155)

Here they are at odds with not only those who advance the VC, but also deontological ethicists, such as Kant, who famously argued that while charging a fair price is in accord with one's duty (that is, behaving virtuously), "this is not nearly enough for making us believe that the merchant has acted this way from duty and from principles of honesty; his own advantage required him to do it [...] the action was done neither from duty nor from immediate inclination, but merely for a selfish purpose" (Kant [1785] 1993, 10; emphasis added).

To be clear, I am not claiming that Storr and Choi's position about robustness is incorrect or indefensible. Market signals like prices and profitability can be important for generating good outcomes. For example, suppose merchants raise their prices on the anticipation of a hurricane. Though sometimes described as price gouging, this behaviour can lead to better outcomes than if they hadn't increased prices. First, it incentivises more traders to enter the market, supplying more goods at a crucial time. Second, higher prices mean that consumers will need to think more carefully about whether they really need the goods in question. So, without formally restricting individual choices, these price increases nevertheless lead to an outcome where more goods are available and where these goods are directed to those who need them most. Sure, the best case scenario might be one in which individuals enter the market without a profit incentive and where individuals voluntarily refrain from frivolous purchases in disasters, but unfortunately human behaviour is far from perfect. Price increases offer a second best solution to the problem, which, given the feasibility constraints that flawed human behaviour imposes, ends up generating the best outcome.

Thus, there are very good reasons for thinking that agents' behaviour should be responsive to profit motives. Storr and Choi think that responsiveness to the profit motive is commendable; proponents of the VC will argue that in many cases it signals that an action is not, in fact, virtuous, 
at least if agents would change their behaviour when the profit motive changes. Thus, it is not the case that those who are moved by the VC are mistaken in their opposition to markets because the values that they care about are actually better instantiated in market societies. Rather, there is a real and deep disagreement between VC proponents and Storr and Choi about what is of most ethical importance: individual motives and the robustness of these motives, or the social outcomes that markets facilitate.

To recap then, I have raised three concerns with Storr and Choi's response to the VC. I think that they have not clearly explained which virtues are most important in determining whether a person is all-thingsconsidered virtuous and thus there is room for disagreement between VC proponents and Storr and Choi about the weights attached to various virtues. I have argued that their interpretation of the content of the virtue of materialism differs from the kinds of concerns that VC proponents have about materialism in markets. And, finally, I have argued that Storr and Choi break with standard accounts of the robustness of virtues by allowing agents to change their behaviour based on the profit motive.

\section{VIRTUES VERSUS CONSEQUENCES}

Early in their book, Storr and Choi acknowledge that

the most damning critiques [of markets] [...] are deontological claims that do not allow for the possibility that market exchange can be moral, what we are calling the common central concern of the moral critics of markets [...] is at root an empirical, rather than a philosophical, claim. As such, we can evaluate whether or not it is true that markets are likely to be morally corrupting using our theoretical understanding of how markets can and should work. (12)

But the problem is that the target phenomenon that they seek to empirically assess is defined differently by different ethical theories. Deontologists, like Kant, are sensitive to the motives on which agents act. Since virtues are dispositions, virtue ethicists are sensitive to something similar: the robustness of actions. ${ }^{2}$ And the problem for Storr and Choi is that the most plausible accounts of both the content and structure of virtues suggests that in many cases markets do crowd out virtuous behaviour.

Although Storr and Choi explicitly argue that markets promote both individual and social virtue, the implicit thrust of their arguments is

\footnotetext{
${ }^{2}$ Though similar, robustness and motives are distinct. See Ferguson (2018) for a discussion.
} 
consequentialist in nature. In chapter 4 they provide extensive evidence that people "in market societies are wealthier, healthier, happier, and better connected than people who live in nonmarket societies" and that these benefits accrue to the poor and rich alike (13). They then claim that "this material fact [...] is of moral significance" (13). And while they are correct that it is of moral significance, they are reporting on the good consequences of markets. Similarly, the virtuous behaviour that they focus onand support with empirical studies-in chapters 5 and 6 is also a consequence. It seems to me that the arguments they really want to make are consequentialist in nature.

SC1 Morally good consequences are more prevalent in market societies than in nonmarket societies.

SC2 As a society becomes more market-oriented and as the scope of the market in a society expands, morally good consequences increase.

SC3 The more a person engages in market activity, the more likely they are to enjoy morally good consequences.

SC4 These consequences are, ultimately, morally more important than considerations like robustness or motives.

And apart from my quibble over their interpretation of materialism, I think Storr and Choi have provided pretty convincing evidence for the truth of these first three claims. But the reason that they do not directly respond to those motivated by the $\mathrm{VC}$ is that they offer no defence of their implicit, but substantial, assumption SC4. I think there are good reasons to think that SC4 is true, at least in most ordinary cases, and so there is good reason to resist VC at this deep ethical level. But contrary to Storr and Choi's caveats, the debate about this crucial claim, and by extension, an adequate response to the $\mathrm{VC}$ depends on the defence of a normative ethical claim that cannot be settled by appeals to empirical evidence.

\section{REFERENCES}

Aristotle. 1999. Nicomachean Ethics. Translated by Terence Irwin. $2^{\text {nd }}$ edition. Indianapolis, IN: Hackett Publishing Company.

Fara, Michael. 2005. "Dispositions and Habituals.” Noûs 39 (1): 43-82.

Ferguson, Benjamin. 2018. “On Love's Robustness.” Ethical Theory and Moral Practice 21 (4): 915-925. 
Hurka, Thomas. 1993. Perfectionism. New York, NY: Oxford University Press.

Kant, Immanuel. (1785) 1993. Grounding for the Metaphysics of Morals. Translated by James Wesley Ellington. $3^{\text {rd }}$ edition. Indianapolis, IN: Hackett Publishing Company.

Manley, David, and Ryan Wasserman. 2008. "On Linking Dispositions and Conditionals." Mind 117 (465): 59-84.

McCloskey, Deirdre. 2006. The Bourgeois Virtues: Ethics for an Age of Commerce. Chicago, IL: University of Chicago Press.

Mill, John Stuart. (1863) 2001. Utilitarianism. Edited by George Sher. $2^{\text {nd }}$ edition. Indianapolis, IN: Hackett Publishing Company.

Nozick, Robert. 1974. Anarchy, State, and Utopia. Oxford: Blackwell.

Stevenson, Angus, ed. 2010. Oxford Dictionary of English. $3^{\text {rd }}$ edition. Oxford: Oxford University Press.

Pettit, Philip. 2015. The Robust Demands of the Good. Oxford: Oxford University Press.

Quine, Willard van Orman. 1960. Word and Object. Cambridge, MA: MIT Press.

Sandel, Michael. 2012. What Money Can't Buy: The Moral Limits of Markets. London: Penguin.

Satz, Debra. 2010. Why Some Things Should Not be for Sale: The Moral Limits of Markets. Oxford: Oxford University Press.

Steiner, Hillel. 1984. “A Liberal Theory of Exploitation.” Ethics 94 (2): 225-241.

Steiner, Hillel. 1994. An Essay on Rights. Oxford: Blackwell.

Benjamin Ferguson is an Associate Professor in the department of Philosophy at the University of Warwick and an Assistant Professor of Ethics at VU Amsterdam. His research focuses on Moral and Political Philosophy, especially on the ethics of market-based interactions like exploitation and fraud. He has also published articles on Kant, moral reasons, and love. Contact e-mail: <benjamin.ferguson@warwick.ac.uk>

Website: <benjaminferguson.org> 